\title{
First Record of Epitokous Metamorphosis and Swimming Behaviour of Glycera nicobarica (Polychaeta: Glyceridae), in the Seto Inland Sea, Western Japan
}

\author{
Yusof Shuaib Ibrahim ${ }^{1,2}$ and Masanori Sato ${ }^{1}$ \\ ${ }^{1}$ Department of Earth and Environmental Sciences, Graduate School of Engineering and Science, \\ Kagoshima University, 1-21-35 Korimoto, Kagoshima 890-0065, Japan \\ ${ }^{2}$ Department of Marine Sciences, Faculty of Marine Science and Maritime Studies, \\ University Malaysia Terengganu, (UMT) 21030 Kuala Terengganu, Terengganu, Malaysia \\ E-mail:ayuk_8101@yahoo.com(YSI); sato@sci.kagoshima-u.ac.jp (MS) \\ ${ }^{2}$ Corresponding author
}

(Received 17 March 2013; Accepted 22 September 2013)

\begin{abstract}
Epitokous metamorphosis and swimming behaviour of the glycerid polychaete Glycera nicobarica Grube, 1866 are recorded for the first time, as the first such observation for any Asian glycerid. A total of 88 mature adults (epitokes) swimming in the surface water were collected from six sites in the Seto Inland Sea, Japan, at various phases of the moon, mostly within two hours after sunset in July to November in 2009 to 2011. By a morphological comparison with 36 immature benthic individuals (atokes) of comparable body size, we confirmed characteristic features of epitokous metamorphosis, including flattening of the body, reduction of the proboscis, enlargement of the parapodia, elongation and increase in number of the chaetae, and addition of simple capillaries in the neuropodia. The epitokous metamorphosis of G. nicobarica is basically similar to those previously described in eight other species of Glycera.
\end{abstract}

Key Words: Glycera nicobarica, reproduction, epitokous metamorphosis, swimming, Seto Inland Sea, Japan.

\section{Introduction}

The genus Glycera, belonging to the family Glyceridae (Polychaeta), includes 44 valid species of carnivorous annelid worms living from intertidal to abyssal depths (Magalhães and Rizzo 2012). Studies on their reproduction are limited, but swimming behaviour of mature males and females for spawning and/or epitokous metamorphosis have been reported from North America, Central America, Europe, and Africa in the following nine species: G. alba (O. F. Müller, 1776), G. americana Leidy, 1855, G. brevicirris Grube, 1870, G. capitata Ørsted, 1842, G. dibranchiata Ehlers, 1868, G. lapidum Quatrefages, 1866, ? G. unicornis Savigny, 1818, G.? sphyrabrancha Schmarda, 1861, and G. tesselata Grube, 1863 (Arwidsson 1898; McIntosh 1910; Chamberlin 1919; Fage and Legendre 1927; Gravier and Dantan 1928; StøpBowitz 1941; Allen 1957; Simpson 1962; Pettibone 1963; Böggemann 2002). Neither epitokous metamorphosis nor swimming behaviour of glycerid species have been recorded from Asia.

Glycera nicobarica Grube, 1866 is distributed along the coasts of the Indian and western Pacific Oceans (Böggemann 2002) and is one of the most common glycerid species inhabiting shallow coastal areas in Japan (Imajima 2007; Yamanishi and Sato 2007). There is no previous report on the reproduction of this species.
During our night sampling of swimming polychaetes in the Seto Inland Sea, Japan, we collected epitokous adults of G. nicobarica. In this paper, we describe their swimming behaviour and epitokous metamorphosis.

\section{Materials and Methods}

Field sampling for sexually mature individuals (epitokes) of Glycera nicobarica was carried out at six sites in the Seto Inland Sea, western Japan (Fig. 1) on a total of 10 days at various phases of the moon in July to November in 2009 to 2011. On each day, one or two persons searched for swimming worms for a minimum of one hour (usually during the period from sunset to midnight) with two kinds of underwater lamps: a strong fish-luring lamp (KU-5MB, $4.5 \mathrm{KW}$, Koto Electric) of the Toyoshio-maru research vessel of Hiroshima University used at four ports (Uno, Okayama Prefecture; Imabari, Ehime Prefecture; Yanai, Yamaguchi Prefecture; Himeshima, Oita Prefecture) (Fig. 1, solid circles 1, 3, 4, 6), and a small, hand-held fish-luring lamp (BF-8952, Panasonic) used at three sites (a small harbor at Tadanoumi, Hiroshima Prefecture; the port of Yanai, Yamaguchi Prefecture; off Nagashima Island, Kaminoseki, Yamaguchi Prefecture) (Fig. 1, solid circles 2, 4, 5). On 10 and 11 November 2010 and on 9 and 10 November 2011, the survey was conducted all night long. A total of 88 epitokous specimens (21 

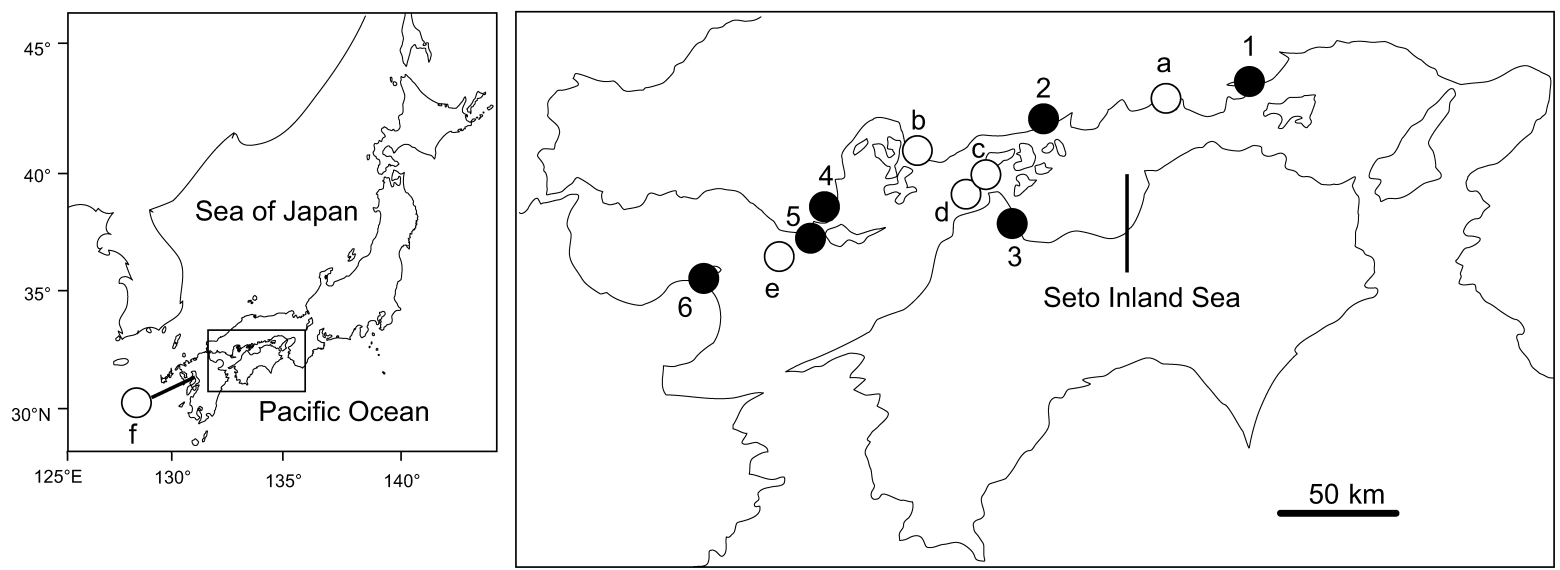

Fig. 1. Collection sites of epitokes (solid circles) and atokes (open circles) of Glycera nicobarica Grube, 1866 in the Seto Inland Sea and Ariake Sea, Japan. 1, Uno Port, Okayama Prefecture; 2, Tadanoumi, Hiroshima Prefecture; 3, Imabari Port, Ehime Prefecture; 4, Yanai Port, Yamaguchi Prefecture; 5, off Nagashima Island, Kaminoseki, Yamaguchi Prefecture; 6, Himeshima Port, Oita Prefecture; a, Kasaoka Bay, Okayama Prefecture; b, Kure, Hiroshima Prefecture; c, Bouchi-no-su, Ehime Prefecture; d, Nukari-no-seto, Hiroshima Prefecture; e, off Iwaijima Island, Yamaguchi Prefecture; f, Kojiro-nagahama, Isahaya Bay, Nagasaki Prefecture.

males, 4 females, and 63 spent worms) were collected with a scoop net as they swam in the surface water. Temperature and salinity of the surface water were measured with an SCT meter (Model 30, Yellow Springs Instrument, Co.). The specimens were fixed in $80 \%$ ethanol or $10 \%$ formalin and transferred to fresh $80 \%$ ethanol for preservation. Their sex was determined by examining the coelomic contents (oocytes or sperm).

A total of 36 immature worms (atokes) were collected from intertidal or subtidal bottoms at five sites in the Seto Inland Sea and one site in the Ariake Sea (Fig. 1) in 1998 to 2011. In intertidal flats at three sites (Kasaoka Bay, Okayama Prefecture; Kure, Hiroshima Prefecture; Kojiro-nagahama, Isahaya Bay, Nagasaki Prefecture), they were obtained from sediment samples dug with a shovel. At three subtidal sites (Bouchi-no-su, Kagawa Prefecture; Nukari-no-seto, Hiroshima Prefecture; off Iwaijima Island, Kaminoseki, Yamaguchi Prefecture), they were obtained from sediment samples dredged at depths of $14-49 \mathrm{~m}$.

Maximum body width (BW) excluding the parapodia and body height $(\mathrm{BH})$ were measured at the same chaetiger within chaetigers $10-30$ for all specimens in the preserved state. Proboscis length (PL) was measured from the base to the tip in ventral view of the everted proboscis, and proboscis width (PW) was measured at the base of the jaws in the anteriormost part of the proboscis. These measurements were carried out using image-processing software (LAS EZ V1.7.0) on photographs taken with a digital camera connected to a stereoscopic microscope (EZ4 D, Leica). Body length (BL) of complete specimens was measured to the nearest $1 \mathrm{~mm}$. Drawings were prepared with a camera lucida. Photographs were taken with a film camera (OM 4, Olympus) for whole body images, and with another film camera (FDX-35, Nikon) on a compound microscope and a digital camera (Coolpix 995, Nikon) on a stereoscopic microscope for enlarged images.
For scanning electron microscopy, small proboscidial fragments of ethanol-preserved specimens were fixed in a $4 \%$ glutaraldehyde solution for one night in small vials, dehydrated in a graded ethanol series, transferred to pure 2-methyl-2-propanol ( $t$-butyl alcohol), and dried using a vacuum dryer (VFD-21, Vacuum Device). Then they were mounted on aluminum stubs and coated with gold-palladium. Observations were performed with a scanning electron microscope (Miniscope TM-1000S, Hitachi).

Terminology of parapodial and chaetal morphology follows that of Böggemann (2002). Specimens are deposited in National Museum of Nature and Science, Tsukuba, Japan (NSMT); Coastal Branch of Natural History Museum and Institute, Chiba, Japan (CMNH); Osaka Museum of Natural History, Japan (OMNH); Senckenberg Museum, Frankfurt, Germany (SMF); and Masanori Sato's personal collection at Kagoshima University, Japan (MS).

\section{Glycera nicobarica Grube, 1866}

[Japanese name: Chirori] (Figs 1-9)

Glycera nicobarica Grube, 1866: 178; Grube 1867: 24-25, pl. 3, figs 1, 1a, b; Böggemann 2002: 57-58, 124-125, figs 67-69; Imajima 2003: 112-113, fig. 67 a-h; Imajima 2007: 30-231, fig. 71 .

Glycera decipiens Marenzeller, 1879: 140, pl. 6, figs 3, 3A.

Glycera amboinensis McIntosh, 1885: 345-346, pl. 42, figs 6, 7.

Glycera chirori Izuka, 1912: 245-246, pl. 2, fig. 8, pl. 24, fig. 13; Okuda 1938: 125, fig. 2; Imajima and Hartman 1964: 161-162; Uchida 1992: 319.

Glycera hasidatensis Izuka, 1912: 246-247, pl. 24, figs 14, 15 (in part).

Material examined. Sexually mature specimens with 
epitokous metamorphosis (epitokes) in the Seto Inland Sea: Uno Port $\left(34^{\circ} 29^{\prime} 33^{\prime \prime} \mathrm{N}, 133^{\circ} 57^{\prime} 26^{\prime \prime} \mathrm{E}, 12 \mathrm{~m}\right.$ deep), Okayama Prefecture, 9-11 November 2010, coll. T. Urata, 10 specimens (MS); 8-10 November 2011, coll. Y. S. Ibrahim, 33 specimens (NSMT-Pol 111422-111423, OMNH-Iv 53545355, 5357-5358, SMF 22825-22827, MS). Imabari Port $\left(34^{\circ} 4^{\prime} 6^{\prime \prime} \mathrm{N}, 133^{\circ} 0^{\prime} 29^{\prime \prime} \mathrm{E}, 7.4 \mathrm{~m}\right.$ deep), Ehime Prefecture, 27 October 2009, coll. M. Sato et al., 14 specimens (CMNHZW 002074-002075, MS). Himeshima Port $\left(33^{\circ} 43^{\prime} 17^{\prime \prime} \mathrm{N}\right.$, $131^{\circ} 38^{\prime} 47^{\prime \prime} \mathrm{E}$ ), Oita Prefecture, 28 October 2009, coll. M. Sato et al., 11 specimens (MS). Yanai Port $\left(33^{\circ} 57^{\prime} 24^{\prime \prime} \mathrm{N}\right.$, $\left.132^{\circ} 8^{\prime} 10^{\prime \prime} \mathrm{E}\right)$, Yamaguchi Prefecture, 29 October 2009, coll. M. Sato et al., 9 specimens (NSMT-Pol 111427, MS); 9 July 2010, coll. Y. S. Ibrahim and M. Sato, 2 specimens (NSMTPol 111426, MS). Tadanoumi $\left(34^{\circ} 19^{\prime} 57^{\prime \prime} \mathrm{N}, 132^{\circ} 59^{\prime} 8^{\prime \prime} \mathrm{E}\right)$, Takehara, Hiroshima Prefecture, 10 July 2010, coll. Y. S. Ibrahim and M. Sato, 5 specimens (NSMT-Pol 111424111425, CMNH-ZW 002077-002078, MS). Off Tanoura $\left(33^{\circ} 47^{\prime} 27^{\prime \prime} \mathrm{N}, 132^{\circ} 1^{\prime} 59^{\prime \prime} \mathrm{E}\right)$, Nagashima Island, Kaminoseki, Yamaguchi Prefecture, 30 July 2011, coll. Y. S. Ibrahim, 4 specimens (MS).

Immature specimens (atokes) in the Seto Inland Sea: Intertidal flats in Kasaoka Bay $\left(34^{\circ} 27^{\prime}-29^{\prime} \mathrm{N}\right.$, $133^{\circ} 31^{\prime}-$ $32^{\prime}$ E), Okayama Prefecture, 13 October 2004, coll. K. Okada, 1 specimen (NSMT-Pol 111428). Intertidal flats in Kawajiri $\left(34^{\circ} 13^{\prime} 1^{\prime \prime} \mathrm{N}, 132^{\circ} 40^{\prime} 13^{\prime \prime} \mathrm{E}\right)$, Kure, Hiroshima Prefecture, 26 February 1998, coll. M. Sato, 5 specimens (NSMTPol 111430, MS). Bouchi-no-su $\left(34^{\circ} 22^{\prime} 29^{\prime \prime}-22^{\prime} 38^{\prime \prime} \mathrm{N}\right.$, $133^{\circ} 36^{\prime} 52^{\prime \prime}-36^{\prime} 53^{\prime \prime}$ E, 23-24 m deep), north of Sanagishima Island in the Shiwaku Islands, Kagawa Prefecture, 8 November 2011, coll. Y. S. Ibrahim, 20 specimens (OMNH-Iv 5356, CMNH-ZW 002076, SMF 22828, MS). Nukari-no-seto $\left(34^{\circ} 18^{\prime} 29^{\prime \prime} \mathrm{N}, 133^{\circ} 13^{\prime} 41^{\prime \prime} \mathrm{E}, 14-15 \mathrm{~m}\right.$ deep), Hiroshima Prefecture, 8 November 2011, coll. Y. S. Ibrahim, 3 specimens (MS). Off Iwaijima Island $\left(33^{\circ} 47^{\prime} 18^{\prime \prime}-47^{\prime} 52^{\prime \prime} \mathrm{N}, 131^{\circ} 59^{\prime} 11^{\prime \prime}-\right.$ $59^{\prime} 22^{\prime \prime}$ E, 20-27 m deep), Yamaguchi Prefecture, 6 May 2000, coll. H. Fukuda, 6 specimens (MS).

Atoke in Ariake Sea: Kojiro-nagahama $\left(32^{\circ} 52^{\prime} 20^{\prime \prime} \mathrm{N}\right.$, $130^{\circ} 15^{\prime} 41^{\prime \prime} \mathrm{E}$ ), Isahaya Bay, Kunimi Town, Nagasaki Prefecture, 2 September 2003, coll. M. Sato, 1 specimen (NSMTPol 111429).

Diagnosis (based on Böggemann 2002). Two types of papillae present on proboscis: conical papillae with $3 \mathrm{U}$ shaped transverse ridges and oval ones without transverse ridges. Ailerons with triangular bases. Biramous parapodia with two prechaetal lobes (notopodial and neuropodial lobes slender, digitiform, of same length throughout) and two postchaetal lobes (notopodial lobe triangular; neuropodial lobe shorter and rounded). Simple digitiform branchiae, situated medially on anterior side of parapodia.

Description of epitokes [based on 88 (18 complete and 70 incomplete) specimens]. Body flattened, $0.8-3.6 \mathrm{~mm}$ in BW, $0.4-2.7 \mathrm{~mm}$ in $\mathrm{BH}$ (Fig. 2A). Largest complete specimen (male) $96 \mathrm{~mm}$ in BL, $2.8 \mathrm{~mm}$ in BW, with 218 chaetigers. Smallest complete specimen (spent worm) $23 \mathrm{~mm}$ in $\mathrm{BL}, 1.6 \mathrm{~mm}$ in BW, with 135 chaetigers. Body color in preserved specimens pale brown to dark brown in both males (Fig. 2A) and females. No significant difference in BW be- tween males (range $1.8-3.6 \mathrm{~mm}$, mean \pm SD $2.5 \pm 0.5 \mathrm{~mm}$, $n=21)$ and females $(2.0-3.2 \mathrm{~mm}, 2.5 \pm 0.5 \mathrm{~mm}, n=4)$ (Wilcoxon-Mann-Whitney test, $P=0.88)$. Sex undeterminable for 63 spent worms $(0.8-3.2 \mathrm{~mm}$ in BW) with all gametes discharged before collection.

Prostomium conical, consisting of 9 to 11 rings altogether as long as first 11-13 chaetigers (Figs 2A, B, 3A). Proboscis cylindrical, PL $4-10 \mathrm{~mm}$ (7-23\% of $\mathrm{BL})$, as long as first 20-40 chaetigers, PW 1-2 mm (Fig. 2A, B). Two types of papillae present on proboscis: conical ones with $3 \mathrm{U}$-shaped ridges (Figs 3B, 4A) and oval ones without ridges (Figs 3C, 4B). Four black, hook-like jaws present on tip of proboscis (Fig. 2B); aileron with triangular base (Fig. 3D) present at base of each jaw.

First 2 pairs of parapodia uniramous, with single acicula, digitiform prechaetal lobe, shorter, rounded postchaetal lobe, and thick, rounded ventral cirrus; ventral cirrus longer than postchaetal lobe (Fig. 5A). All following parapodia biramous, with 2 aciculae, 2 prechaetal lobes, 2 postchaetal lobes, and ventral cirrus. Two prechaetal lobes slender and triangular, of almost same length in anterior and middle parapodia; neuropodial prechaetal lobe longer than notopodial one in posterior parapodia. Two postchaetal lobes shorter than prechaetal lobes throughout; both lobes rounded, of same length in anteriormost parapodia back to about chaetiger 10; notopodial postchaetal lobe triangular with tapering tip, slightly longer than round neuropodial one in middle parapodia (Fig. 5B-D); both lobes triangular, of same length in posterior parapodia (Fig. 5E). Dorsal cirrus absent in parapodium 1, usually present from parapodium 2 (sometimes from parapodium 3) onward; dorsal cirrus oval, inserted into body wall above parapodial base in anterior body back to about chaetiger 20 ; dorsal cirrus attached to upper edge of parapodial base in following chaetigers. Ventral cirrus triangular, about as long as neuropodial postchaetal lobe throughout.

Branchiae retractile, simple, and digitiform, appearing from parapodia 16-31 to near posterior end, situated medially on anterior side of parapodia, largest in middle or posterior parapodia (Fig. 3E).

Notochaetae all simple capillaries throughout, 3-13, $4-19$, and 2-8 in anterior (chaetigers 10-20), middle (chaetigers 50-110), and posterior (chaetigers 160-210) parapodia, respectively (Figs 3F, 6A). Upper neurochaetae all spinigerous compound chaetae, numbering 1-11, 1-11, and 1-4 in anterior, middle, and posterior parapodia, respectively (Figs 3G, 6A). Lower neurochaetae consisting of spinigerous compound chaetae at upper position, numbering $0-17$, $2-16$, and $1-8$ in anterior, middle, and posterior parapodia, respectively; simple capillaries at lower position, numbering $0-3,0-7$, and $0-2$ in anterior, middle, and posterior parapodia, respectively. All chaetae elongated, longest in middle parapodia.

Head of spermatozoa round, about $3 \mu \mathrm{m}$ long, $3 \mu \mathrm{m}$ wide (Fig. 2D). Oocytes 140-150 $\mu \mathrm{m}$ in diameter.

Comparison of morphology between atokes and epitokes. Morphological characteristics of the 88 swimming epitokes $(0.8-3.6 \mathrm{~mm}$ in $\mathrm{BW}$, mean $\pm \mathrm{SD}: 2.1 \pm 0.5 \mathrm{~mm})$ were 

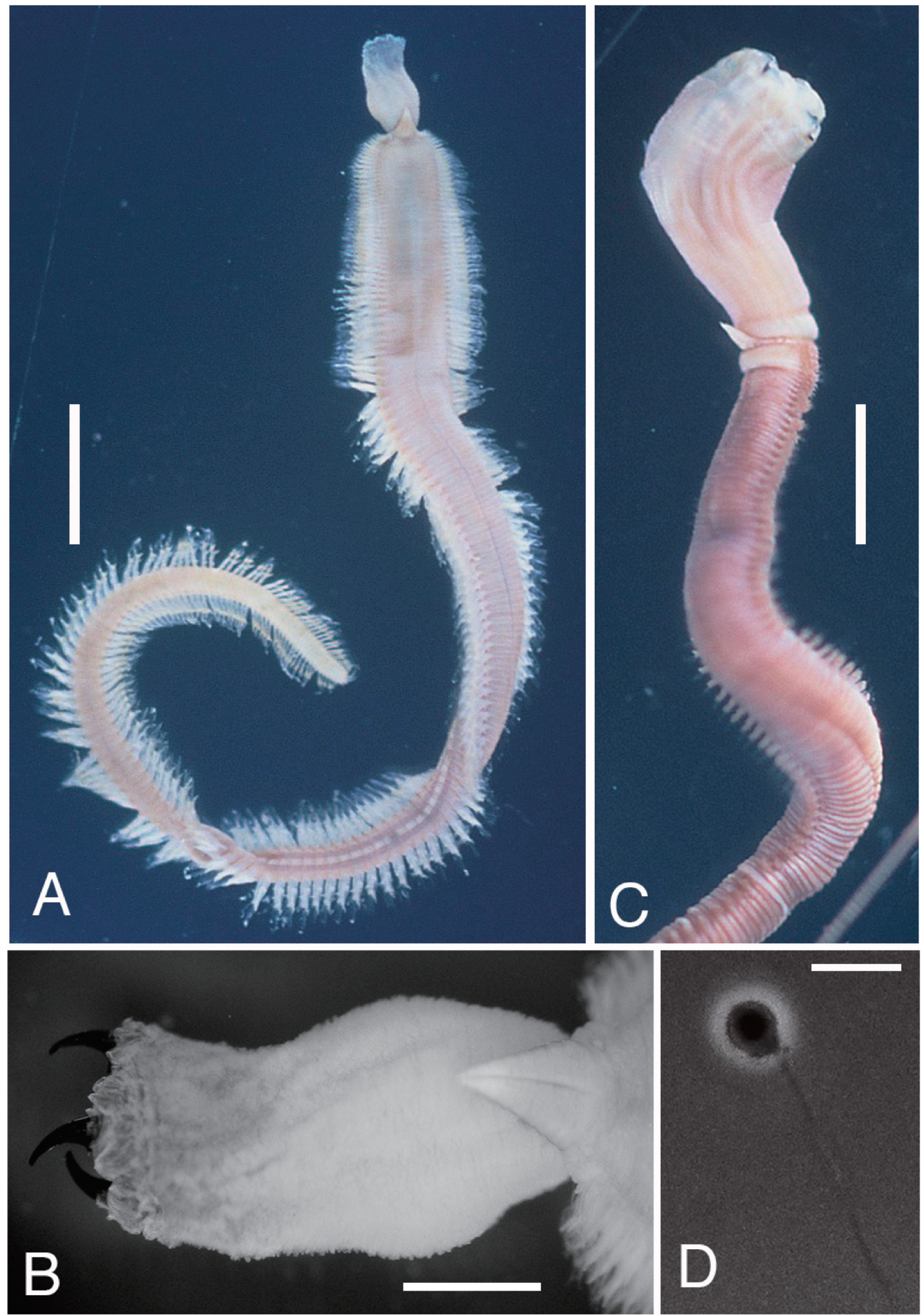

Fig. 2. Glycera nicobarica Grube, 1866. A, Whole body, epitokous male (NSMT-Pol 111422), dorsal view; B, enlargement of proboscis and prostomium, epitokous male (NSMT-Pol 111422), dorsal view; C, anterior part of an atoke with everted proboscis (NSMT-Pol 111429), lateral view; D, spermatozoon obtained from an epitokous male (NSMT-Pol 111426). Scale bars: $5 \mathrm{~mm}$ (A, C); $1 \mathrm{~mm}$ (B); $5 \mu \mathrm{m}$ (D). 

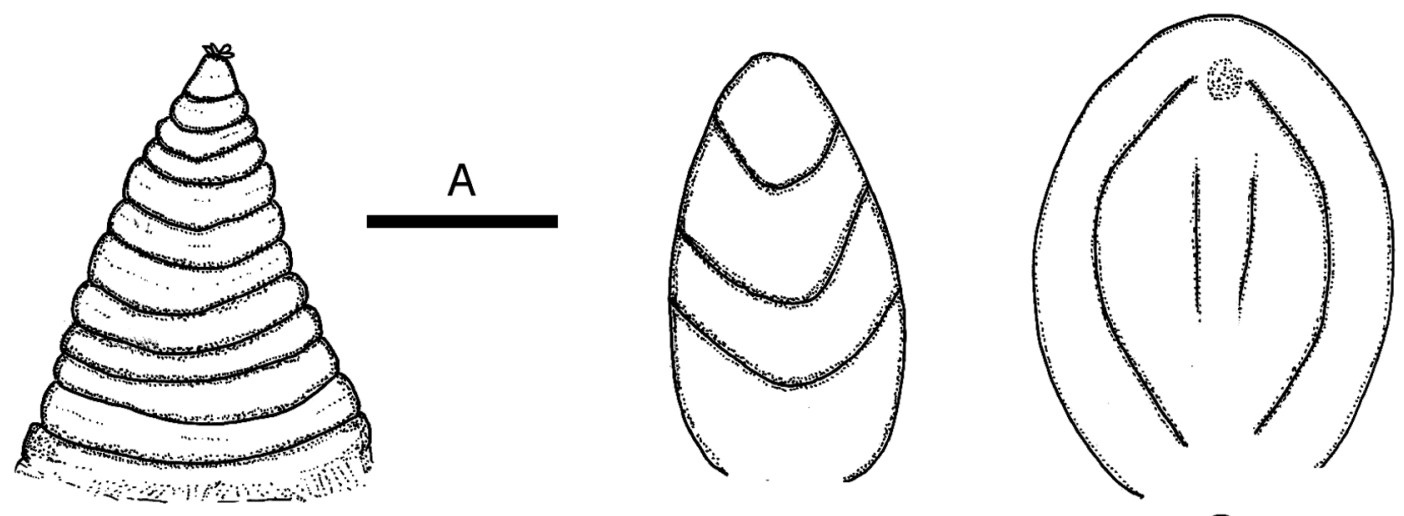

$\mathrm{B}, \mathrm{C}$

A
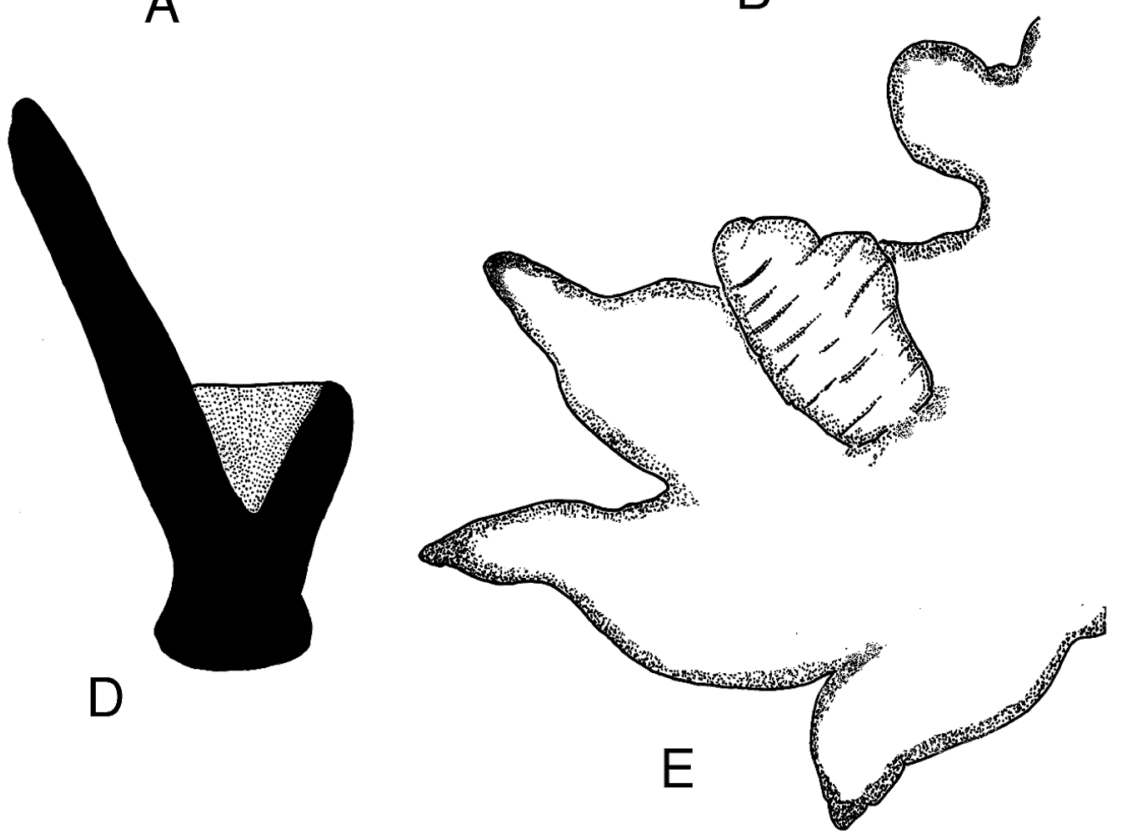

$\mathrm{D}, \mathrm{E}$

$\mathrm{F}, \mathrm{G}$

C

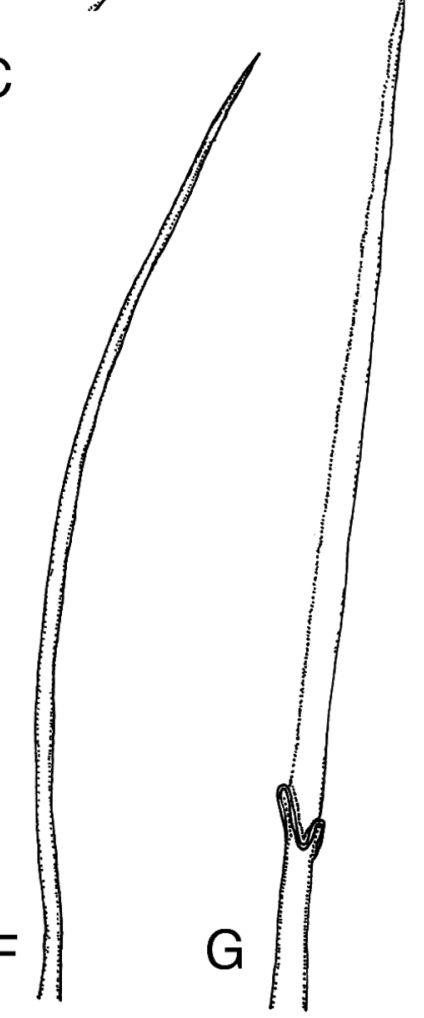

Fig. 3. Epitokous female of Glycera nicobarica Grube, 1866 (NSMT-Pol 111427). A, Dorsal view of prostomium with 11 rings; B, conical papilla on proboscis with $3 \mathrm{U}$-shaped ridges; C, oval papilla on proboscis; D, aileron with triangular base; E, right parapodium of chaetiger 34 with everted branchia, anterior view; F, simple capillary from notopodium of chaetiger 110; G, spinigerous compound chaeta from neuropodium of chaetiger 110. Scale bars: $1 \mathrm{~mm}(\mathrm{~A}) ; 0.02 \mathrm{~mm}$ (B, C); $0.2 \mathrm{~mm}(\mathrm{D}, \mathrm{E}) ; 0.01 \mathrm{~mm}(\mathrm{~F}, \mathrm{G})$.

compared with those of 35 benthic atokes of comparative body size (BW $1.0-3.0 \mathrm{~mm}, 2.2 \pm 0.5 \mathrm{~mm}$ ); there was no significant difference in BW between the epitokes and atokes (Wilcoxon-Mann-Whitney test, $P=0.07$ ). Epitokous males and females were pale or dark brown in body color whereas both living and ethanol-preserved specimens of atokes were reddish-brown (Fig. 2A,C). The body wall of epitokes was thinner than that of atokes.

The body became flattened in epitokes. $\mathrm{BH}$ of epitokes $(0.4-2.7 \mathrm{~mm}, 1.2 \pm 0.5 \mathrm{~mm}, n=88)$ was significantly less than that of atokes $(0.9-3.0 \mathrm{~mm}, 2.0 \pm 0.5 \mathrm{~mm}, n=35)$ $(P<0.0001)$. The thickness index $(\mathrm{BH} / \mathrm{BW})$ of epitokes $(0.2-$ $1.0,0.6 \pm 0.2, n=88)$ was significantly smaller than that of atokes $(0.9-1.0,0.9 \pm 1.1, n=35)(P<0.0001)$.

The proboscis of epitokes was markedly reduced in size.
PL of epitokes $(3.2-5.4 \mathrm{~mm}, 4.0 \pm 0.8 \mathrm{~mm}, n=10)$ was significantly smaller than that of atokes $(3.3-9.8 \mathrm{~mm}, 6.0 \pm$ $2.0 \mathrm{~mm}, n=14) \quad(P=0.005)$ (Fig. $2 \mathrm{~A}, \mathrm{C}) . \mathrm{PW}$ of epitokes $(1.0-1.7 \mathrm{~mm}, 1.4 \pm 0.2 \mathrm{~mm}, n=10)$ was significantly smaller than that of atokes $(2.1-4.5 \mathrm{~mm}, 3.0 \pm 0.7 \mathrm{~mm}, n=14)$ $(P<0.0001)$.

The parapodia of epitokes (Fig. 5A-E) were enlarged throughout in comparison to those of atokes (Fig. 5F-J), with chaetae elongated and increased in number (Fig. $6 \mathrm{~A}, \mathrm{~B}$ ). Numbers of notochaetae (simple capillaries, up to 12), upper neurochaetae (spinigerous compound chaetae, up to 8), and lower neurochaetae (spinigerous compound chaetae, up to 11$)$ in atokes $(n=3)$ were smaller than those of epitokes (up to 19,11 , and 17 , respectively) $(n=13)$. Simple capillaries appeared not only on notopodia but also on 

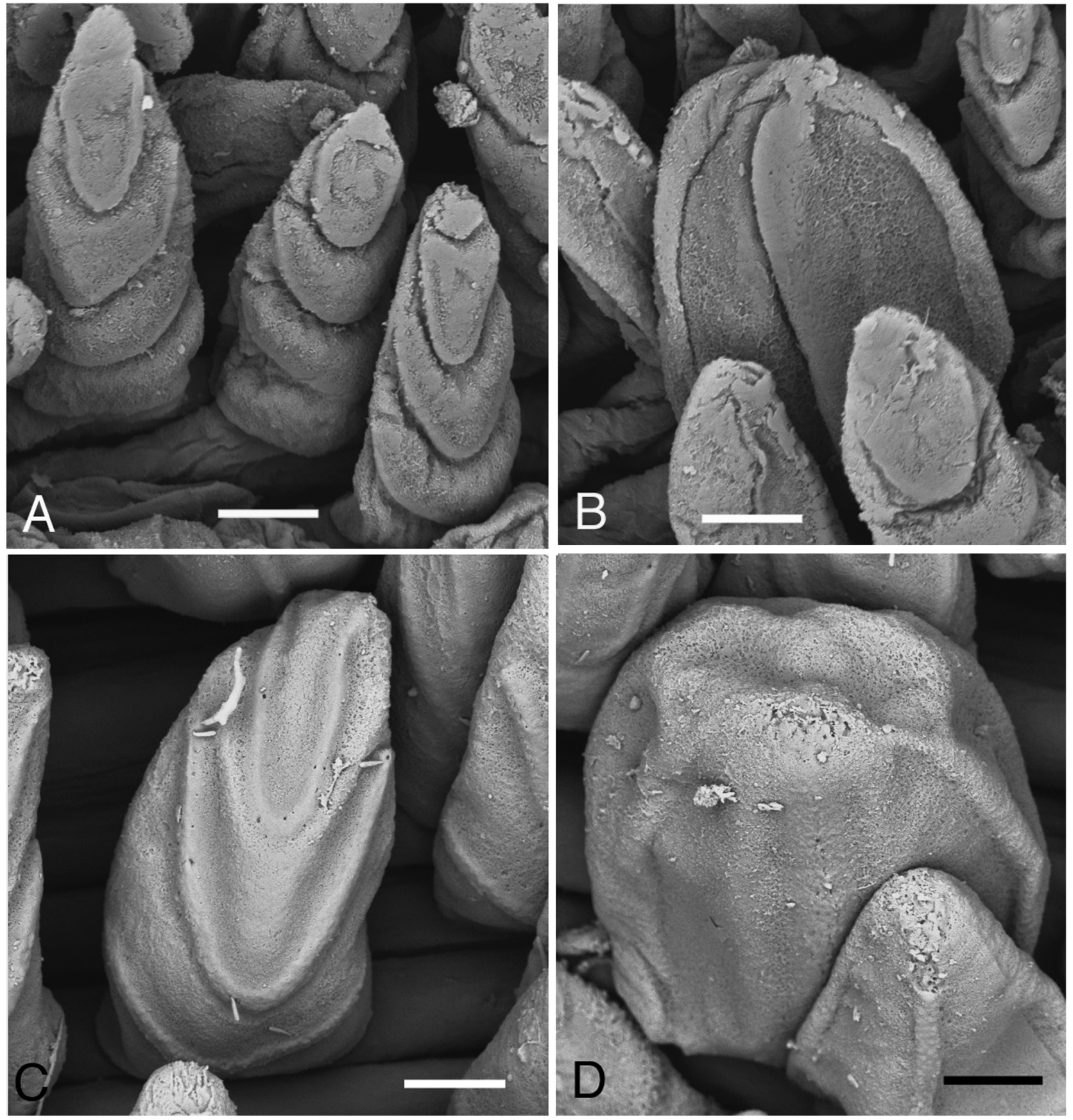

Fig. 4. Glycera nicobarica Grube, 1866. Scanning electron micrographs of two kinds of papillae on proboscis. A, B, Epitokous male (NSMT-Pol 111423); C, D, atoke (NSMT-Pol 111429). A, C, conical papillae with 3 U-shaped ridges; B, D, oval papilla. Scale bars: $10 \mu \mathrm{m}$.

neuropodia (inferior portion) in epitokes, whereas they appeared only on notopodia in atokes.

Symbionts. Several small organisms including copepods (Fig. 7A, B) and nematodes (Fig. 7C,D) were attached to the body wall and parapodia of four epitokous males and seven spent worms (Fig. 7). The copepods (Fig. 7A, B) were identified as belonging to the family Clausiidae (Copepoda: Cyclopoida) (Susumu Ohtsuka, pers. comm.). The relationship between these symbionts and the epitokous worms is unknown. No symbionts were observed in atokous specimens.
Swimming behaviour of epitokes. Epitokes were collected throughout our sampling period (July to November) in the Seto Inland Sea. Many specimens were collected from the end of October to early November (Fig. 8). Their dates of occurrence were not related to any specific moon phases (2.9-28.8). Water temperatures and salinities at sampling sites were recorded as $20-25^{\circ} \mathrm{C}$ and $29-32 \mathrm{psu}$, respectively. Most epitokes $(n=81)$ were collected in the evening (17:0021:40) within two hours after sunset, although a few epitokes were collected at midnight $(0: 00-1: 15, n=6)$ or early morning before sunrise $(4: 05, n=1)$, with no relation to 

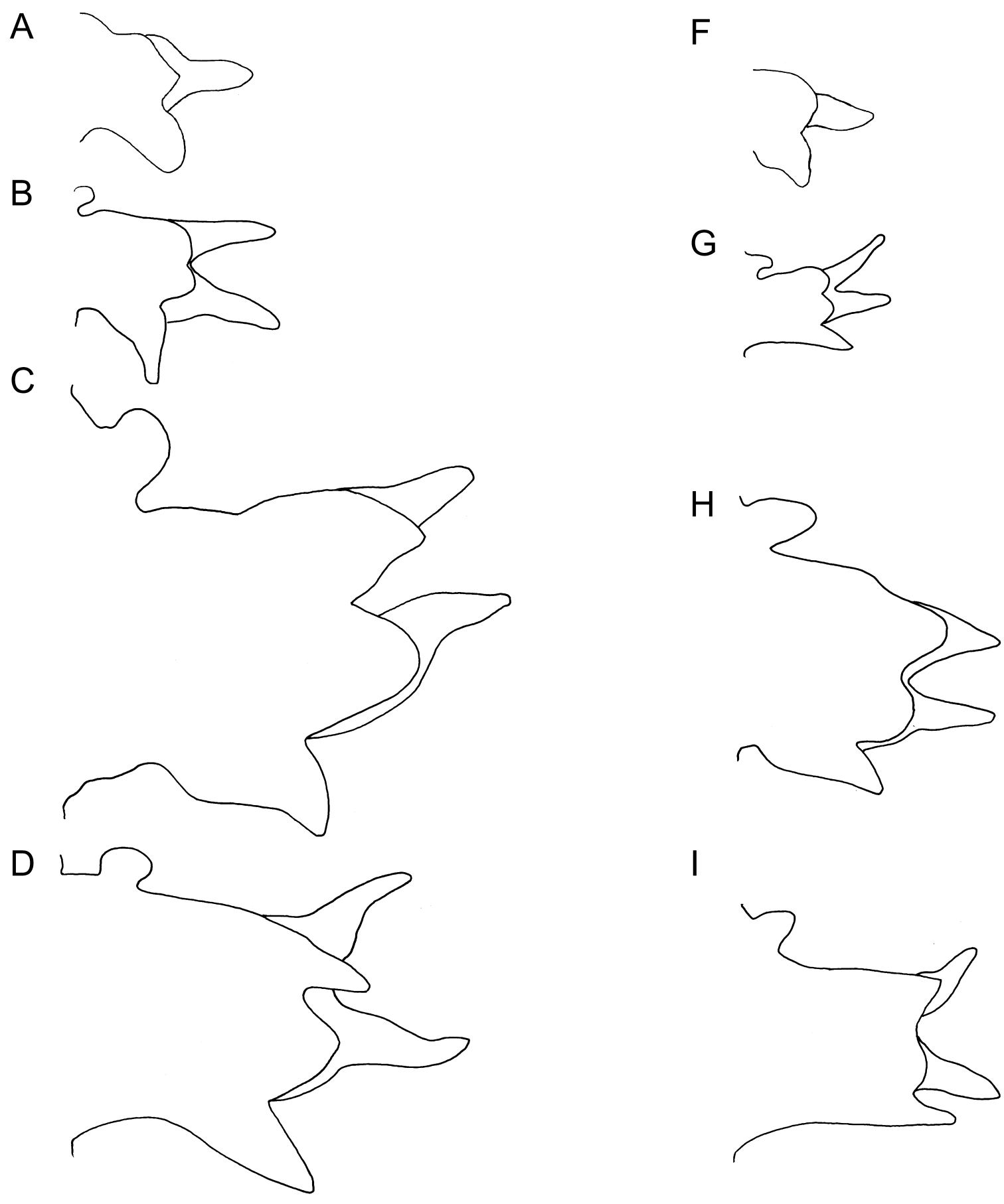

$E$

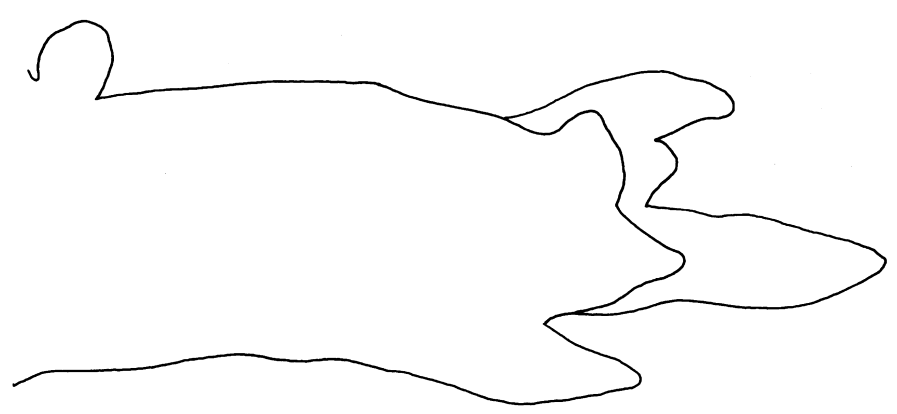

$\mathrm{J}$

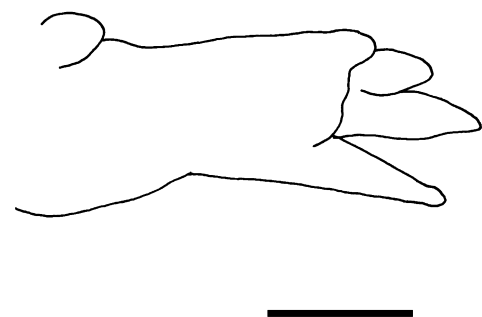

Fig. 5. Glycera nicobarica Grube, 1866. Comparison of parapodia between epitokes (A-E) and atokes (F-J) of comparable body width, posterior view. A, Epitokous male, $2.8 \mathrm{~mm}$ BW, NSMT-Pol 111424; B-D, epitokous female, $2.0 \mathrm{~mm}$ BW, NSMT-Pol 111427; E, epitokous female, $2.6 \mathrm{~mm}$ BW, CMNH-ZW 002078; F, J, atoke, $2.8 \mathrm{~mm}$ BW, NSMT-Pol 111430; G-I, atoke, $1.8 \mathrm{~mm}$ BW, NSMT-Pol 111428. A, F, Chaetiger 1; B, G, chaetiger 4; C, H, chaetiger 34; D, I, chaetiger 110; E, J, chaetiger 180. Scale bar: $0.2 \mathrm{~mm}$. 


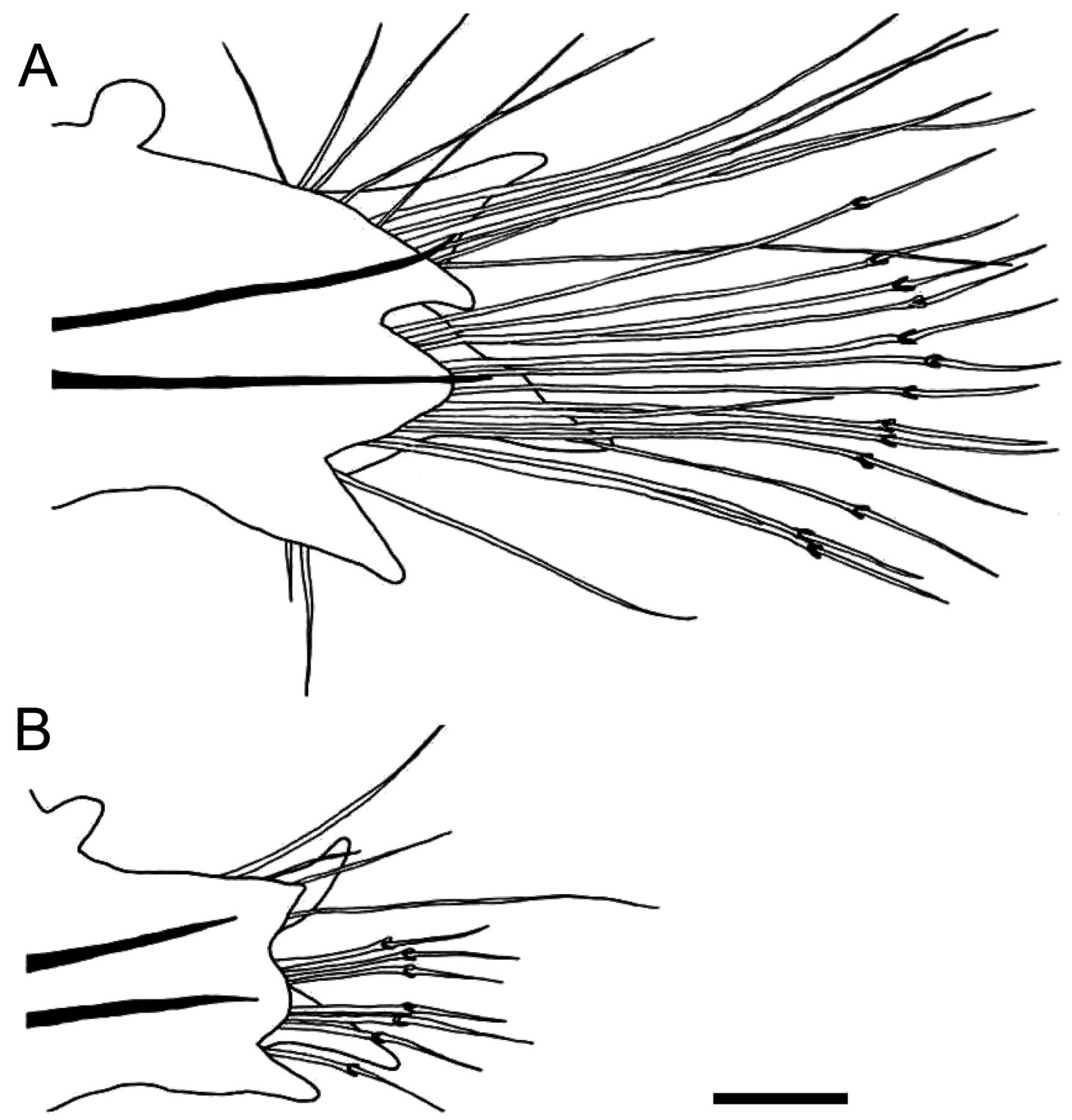

Fig. 6. Glycera nicobarica Grube, 1866. Comparison of parapodia and chaetal arrangement in chaetiger 110 between epitoke (A) and atoke (B), posterior view. A, Epitokous female, $1.9 \mathrm{~mm}$ BW, NSMT-Pol 111427; B, atoke, $1.8 \mathrm{~mm}$ BW, NSMT-Pol 111428. Scale bar: $0.2 \mathrm{~mm}$.

tidal condition (Fig. 8).

Epitokes swam slowly, straight and head first in surface water, showing a wave-like movement. We do not use the term "swarming" for their swimming behaviour because we did not find mass swimming, which is well-known in epitokes of some nereidids, syllids, and eunicids (Clark 1961). In most cases, we observed only a few individuals swimming at the surface water except in Uno port on 9 November 2011, when we collected relatively many epitokes within a short period: 17 individuals in $15 \mathrm{~min}$ (18:15-18:30) (Fig. 8 ). We observed some epitokes shedding their whitish gametes through the body wall during swimming. Small holes or slits, which are probably the sites of gamete discharge, were often found around the ventral surface of the base of the parapodia in the middle body (chaetigers 47-143) of 22 epitokous worms (Fig. 9).
Geographical distribution. Indian Ocean, coasts of Japan, East and South China Seas (Böggemann 2002).

Remarks. The author and year of the original description of Glycera nicobarica has been referred to as "Grube, 1868 " by previous authors (e.g., Böggemann 2002). But recently Böggemann (pers. comm.) discovered an earlier publication of the description of this species (Grube 1866).

\section{Discussion}

Epitokous metamorphosis and swimming behaviour of Glycera nicobarica were recorded for the first time in the present study, also for the first time for any Asian glycerid.

Polychaetes that become pelagic at sexual maturity undergo some degree of structural alteration into specialized 

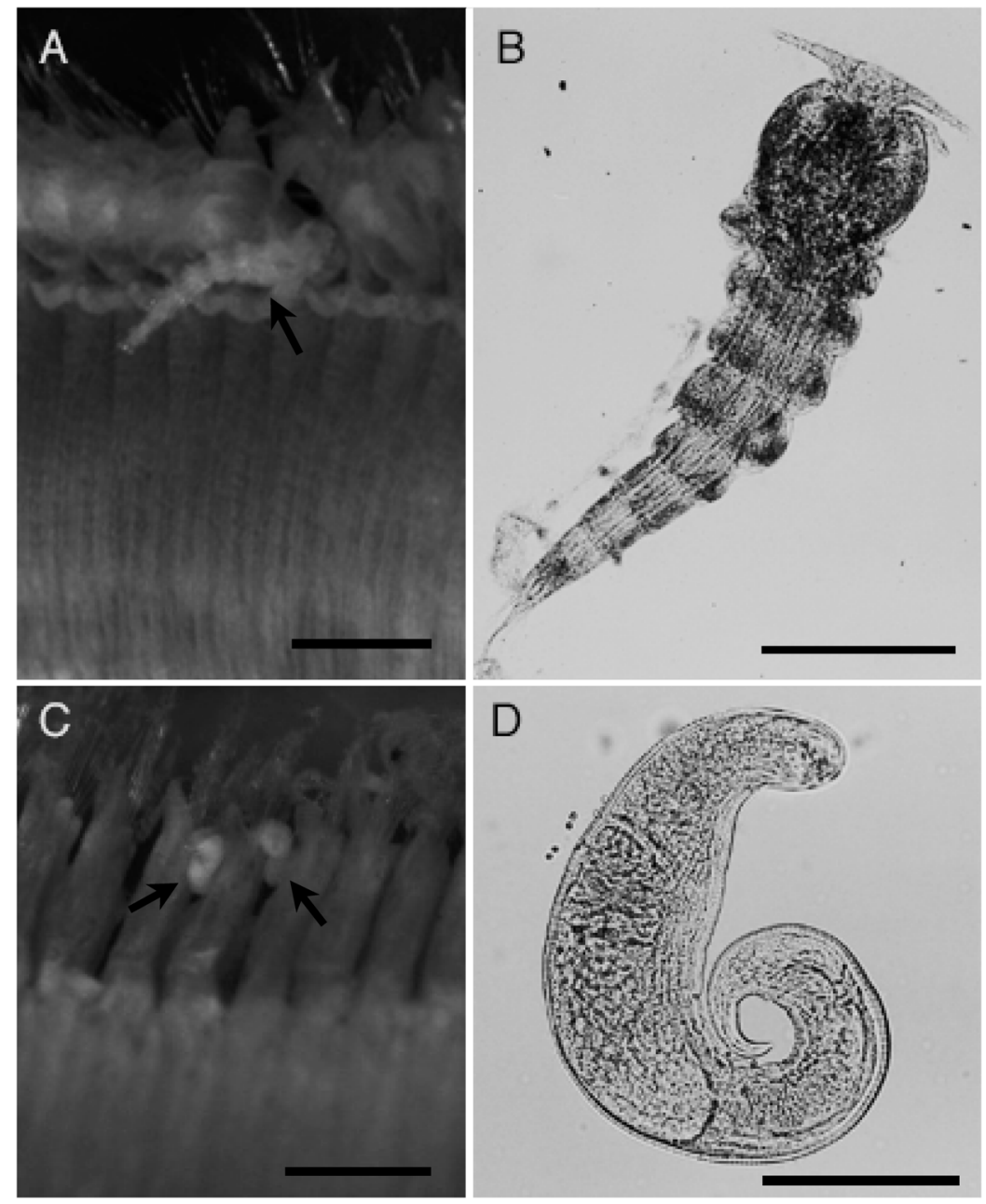

Fig. 7. Presumed parasites attached to epitokous males of Glycera nicobarica Grube, 1866. A, Copepod (arrow) (NSMT-Cr 22387) attached to parapodia of male (NSMT-Pol 111425); B, enlargement of copepod, dorsal view; C, nematodes (arrows) (NSMT-As 3962) attached to parapodia in mid-body of another male (NSMT-Pol 111424); D, enlargement of nematode. Scale bars: $0.5 \mathrm{~mm}$ (A-C); $0.1 \mathrm{~mm}$ (D).

reproductive forms, known as epitokes (Clark 1961). Epitokous metamorphosis in Glyceridae has been reported previously in eight species in North America, Central America, Europe, and Africa (Table 1). Most of the morphological changes observed in the epitokous metamorphosis of $G$. nicobarica are similar to those of these species: the reduced thickness of the body wall, reduced proboscis, enlarged parapodia, elongation and increase in number of the chaetae, and addition of simple capillaries in the neuropodia (Table 1). Flattening of the body was not reported in the previous studies, and is recorded herein for the first time as an epitokous characteristic in glycerids. In most cases epitokous metamorphosis in glycerids occurs throughout the length of the body, but that of G. brevicirris (male: Chamberlin 1919) and that of G. tesselata (Gravier and Dantan 1928) occur only in the middle and posterior parts of the body, respectively.

The reduction of the proboscis and gut seems to indicate that the epitokes stop feeding after their metamorphosis and die after reproduction, as has also been suggested for G. dibranchiata (Klawe and Dickie 1957; Creaser 1973). The en- largement of the parapodia, as well as the elongation and increase in number of the chaetae, no doubt improve the swimming ability of epitokes, as was also suggested by StøpBowitz (1941).

The egg diameter of $G$. nicobarica $(140-150 \mu \mathrm{m})$ is comparable to that of $G$. dibranchiata ( $140 \mu \mathrm{m}$ : Simpson 1962; 150-160 $\mu \mathrm{m}$ : Creaser 1973).

We could not find any relationship between the occurrence of epitokous swimming and a specific phase of the moon. In contrast, the epitokous swimming of G. lapidum coinciding with the last quarter moon in December, January, and February (Fage and Legendre 1927).

In the present study, we collected most of the swimming epitokes of G. nicobarica in the evening within two hours after sunset, with no relation to specific tidal condition. Swimming epitokes of G. lapidum and G. tesselata were also collected shortly after sunset (Fage and Legendre 1927; Gravier and Dantan 1928). On the other hand, swimming epitokes of $G$. dibranchiata were taken in the afternoon, i.e., at 15:00-17:30 around the time of high tide (Simpson 1962; Creaser 1973). 


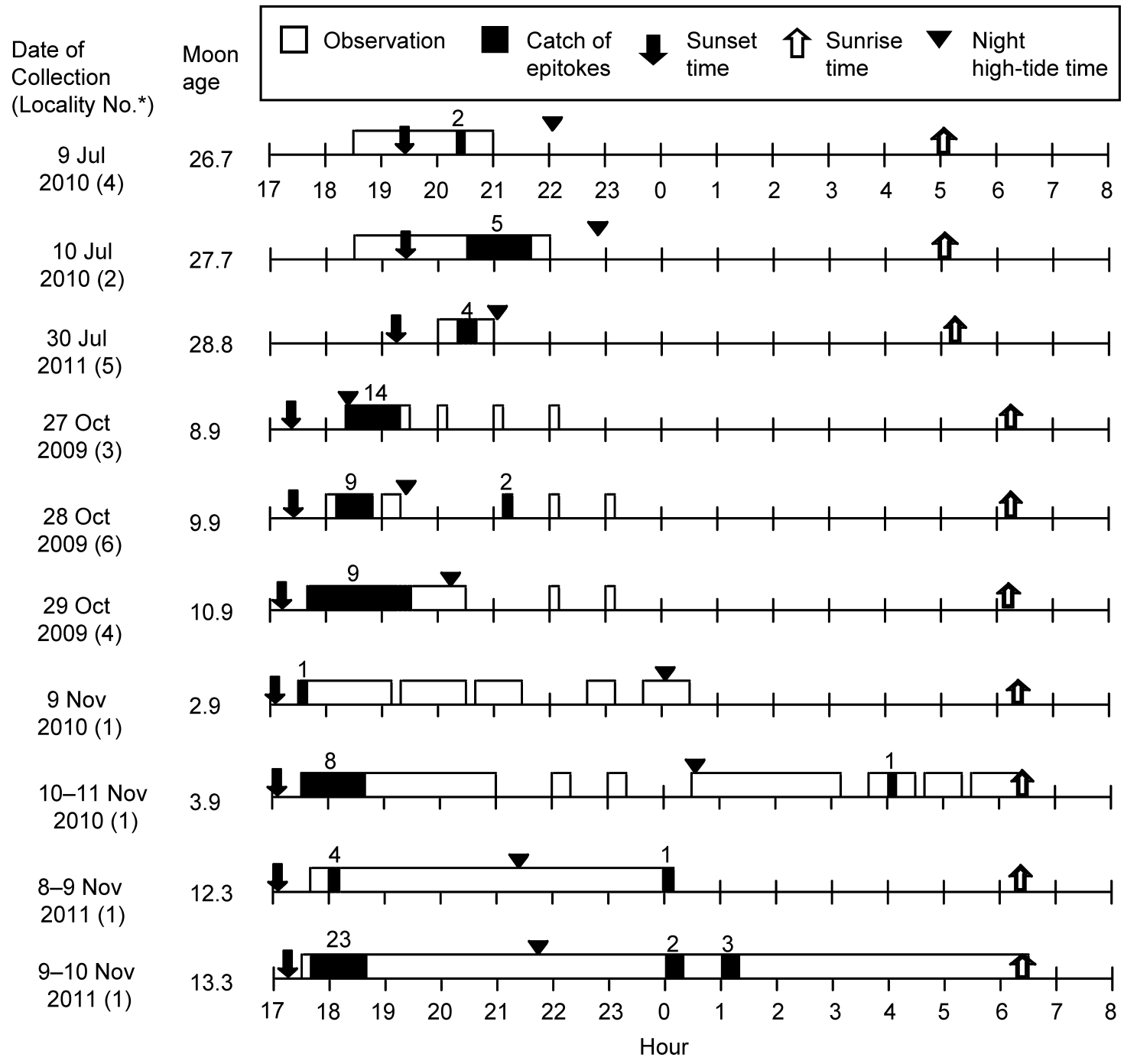

Fig. 8. Timing of reproductive swimming of epitokes of Glycera nicobarica Grube, 1866 at six sites in July to November in 2009 to 2011. Numbers above black squares indicate the number of epitokes collected on each ocassion. The locality numbers $\left({ }^{\star}\right)$ correspond to those in Fig. 1.

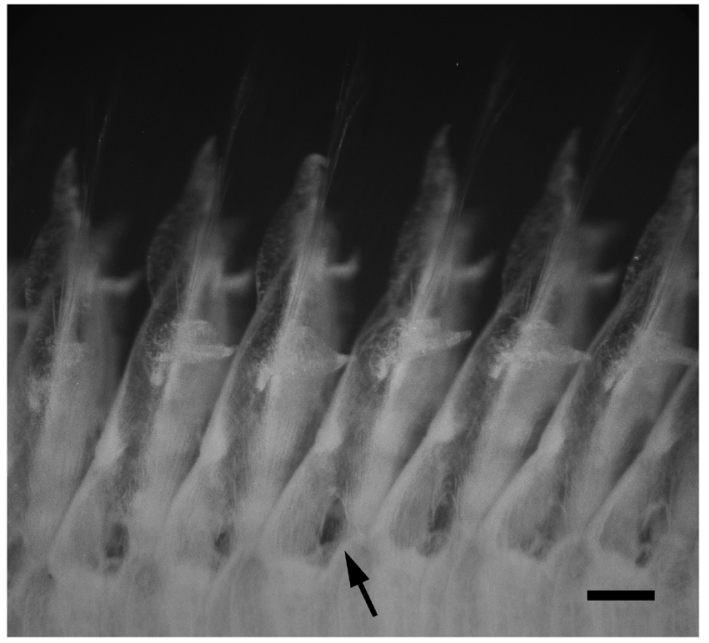

Fig. 9. Small holes (one arrowed) on ventral surface of bases of parapodia of spent G. nicobarica Grube, 1866 (MS). Scale bar: $0.1 \mathrm{~mm}$.
The swimming epitokes of glycerid species seem not to form dense swarms. The density of the swimming epitokes of $G$. nicobarica was low and comparable to that reported in G. dibranchiata (one worm per $36 \mathrm{~m}^{2}$ surface area: Creaser 1973). Epitokous swimming and spawning in glycerids may occur not only in surface water but also in bottom water. Using SCUBA, Creaser (1973) observed a swimming epitokous male of $G$. dibranchiata that spawned near the bottom.

The swimming behaviour of the epitokes of $G$. nicobarica is similar to that described for G. dibranchiata by Simpson (1962). As for spawning, previous authors have reported that the gametes are shed from the proboscis, the body wall, or the posterior end of the body in G. dibranchiata (Klawe and Dickie 1957; Simpson 1962; Creaser 1973). In G. nicobarica, the gametes seem to be discharged from ruptures in the body wall around the ventral surface of the parapodia, and also from the posterior end of the body when it was detached.

Pairing behaviour of male and female, which is known as 


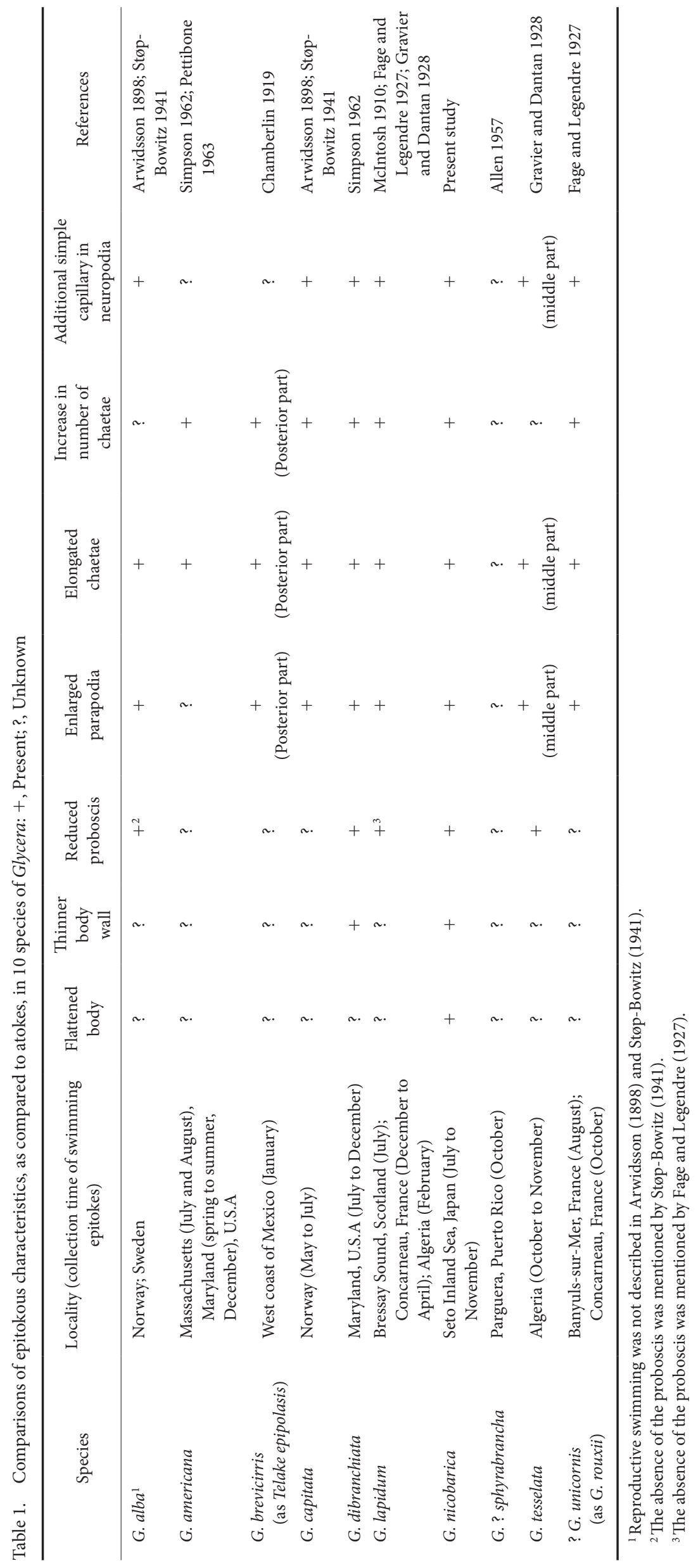


a "nuptial dance" in some nereidid species (Clark 1961; Hardege and Bartels-Hardege 1995), has never been observed in glycerid epitokes.

Night-swimming behaviour of pre-mature adults is known in G. dibranchiata (see Dean 1978), but we did not find any swimming pre-mature adults of G. nicobarica that had not undergone epitokous metamorphosis.

\section{Acknowledgments}

We sincerely thank Hiroyuki Motomura, Hiroshi Kajihara, Markus Böggemann, and an anonymous reviewer for their critical reading of the manuscript. We also thank Takao Suzuki (Tohoku University), Susumu Ohtsuka and staff of the vessel Toyoshio-maru (Hiroshima University), Kazuki Okada (Mihara, Hiroshima Prefecture), Hiroshi Fukuda (Okayama University), and Toshihiro Urata (Kagoshima University) for help in collecting specimens. This work was partially supported by the University Malaysia, Terengganu (UMT) and The Ministry of Higher Education of Malaysia (KPT).

\section{References}

Allen, M. J. 1957. The breeding of polychaetous annelids near Parguera, Puerto Rico. The Biological Bulletin 113: 49-57.

Arwidsson, I. 1898. Studien über die Familien Glyceridae und Goniadidae. Bergens Museums Aarbog 11: 1-69, pls 1-4.

Böggemann, M. 2002. Revision of the Glyceridae Grube 1850 (Annelida: Polychaeta). Abhandlungen der Senckenbergischen Naturforschenden Gesellschaft 555: 1-249.

Chamberlin, R. V. 1919. The Annelida Polychaeta. Memoirs of the Museum of Comparative Zoölogy at Harvard College 48: 1-514, pls $1-80$.

Clark, R. B. 1961. The origin and formation of the heteronereis. Biological Reviews 36: 199-236.

Creaser, E. P. Jr. 1973. Reproduction of the bloodworm (Glycera dibranchiata) in the Sheepscot Estuary, Maine. Journal of the Fisheries Research Board of Canada 30: 161-166.

Dean, D. 1978. The swimming of bloodworms (Glycera spp.) at night, with comments on other species. Marine Biology 48: 99-104.

Fage, L. and Legendre, R. 1927. Pêches plantoniques à la lumière, effectuées à Banyuls-sur-Mer et à Concarneau. I. Annélides Polychètes. Archives de Zoologie Expérimentale et Générale 67: 23-222.

Gravier, C. and Dantan, J. L. 1928. Pêches nocturnes à la lumière dans la baie d'Alger. Annales de l'Institut Océanographique, Paris, Nouvelle Serie 5: 1-186.

Grube, E. 1866. Beschreibungen neuer von der Novara-Expedition mitgebrachter Anneliden und einer neuen Landplanarie. Verhandlugen der Kaiserlich-Königlichen Zoologisch-Botanischen Gesellschaft in Wien 16: 173-184.

Grube, E. 1867. Reise der Österreichischen Fregatte Novara um die Erde in den Jahren 1857, 1858, 1859. Unter den Befehlen des Commodore B. von Wüllerstorf-Urbair. Zoologischer Theil, Vol. 2, Part 3, Anneliden. Kaiserlich-Königlichen Hof- und Staatsdruckerei, Wien, 46 pp., 4 pls.

Hardege, J. D., Bartels-Hardege, H. and Hardege, J. D. 1995. Spawning behavior and development of Perinereis nuntia var. brevicirrus (Annelida: Polychaeta). Invertebrate Biology 114: 39-45.

Imajima, M. 2003. Polychaetous annelids from Sagami Bay and Sagami Sea collected by the Emperor Showa of Japan and deposited at the Showa Memorial Institute, National Science Museum, Tokyo (II). Orders included within the Phyllodocida, Amphinomida, Spintherida and Eunicida. National Science Museum Monographs 23: $1-221$.

Imajima, M. 2007. Kankeidoubutsu Tamourui III [Annelida, Polychaeta, Vol. III]. Biological Research Co., Tokyo, v+499 pp. [In Japanese]

Imajima, M. and Hartman, O. 1964. The polychaetous annelids of Japan. Part I. Allan Hancock Foundation Publications, Occasional Paper 26: 1-237.

Izuka, A. 1912. The errantiate Polychaeta of Japan. The Journal of the College of Science, Imperial University of Tokyo 30: 1-262, pls $1-24$.

Klawe, W. L. and Dickie, L. M. 1957. Biology of the bloodworm Glycera dibranchiata Ehlers, and its relation to the bloodworm fishery of the Maritime Provinces. Bulletin of the Fisheries Research Board of Canada 115: 1-37.

Magalhães, W. F. and Rizzo, A. E. 2012. Glyceridae (Annelida: Polychaeta) from Guam, Mariana Islands with description of a new species of Glycera Savigny in Lamarck, 1818. Zootaxa 3338: 60-68.

Marenzeller, E. 1879. Südjapanische Anneliden. Denkschriften der Kaiserlichen Akademie der Wissenschaften, Mathematisch-Naturwissenschaftliche Classe 41: 109-154, pls 1-6.

McIntosh, W. C. 1885. Report on the Annelida Polychaeta collected by H. M. S. Challenger during the years 1873-1876. Report on the Scientific Results of the Voyage of H. M. S. Challenger during the years 1873-76, Zoology 12: 1-554, pls 1-55.

McIntosh, W. C. 1910. Monograph of the British Annelids. Part II. Polychaeta. Syllidae to Ariciidae. Ray Society, London, pp. 233-524, pls 51-56 and 71-87.

Okuda, S. 1938. Polychaetous annelids from the Isé Sea. Zoological Magazine, Tokyo 50: 122-131. [In Japanese with English abstract]

Pettibone, M. H. 1963. Marine polychaete worms of the New England Region. 1. Families Aphroditidae through Trochochaetidae. United States National Museum Bulletin 227: 1-356.

Simpson, M. 1962. Reproduction of the polychaete Glycera dibranchiata at Solomons, Maryland. The Biological Bulletin 123: 396-411.

Støp-Bowitz, C. 1941. Les glycériens de Norvège. Nytt Magasin for Naturvidenskapene 82: 181-250.

Uchida, H. 1992. Polychaeta. Pp. 310-373. In: Nishimura, S. (Ed.) Guide to Seashore Animals of Japan with Color and Keys, Vol I. Hoikusha, Osaka. [In Japanese]

Yamanishi, R. and Sato, M. 2007. [Class Polychaeta]. Pp. 182-192. In: Ijima, A. (Ed.) Dai 7 Kai Shizen Kankyō Hozen Kisō Chōsa Senkaiiki Seitaikei Chōsa (Higata Chōsa) Hōkokusho [Report of the 7th National Survey on the Natural Environment: Shallow Sea Survey (Tidal Flat Survey)]. Biodiversity Center, Nature Conservation Bureau, Ministry of the Environment, Fuji-Yoshida, Japan. [In Japanese] 